\title{
The Social Characteristics of Postgraduate Students in Ecuador: A Multidimensional Statistical Analysis
}

\author{
Andrés Bonilla Marchán ${ }^{1}$, Ramiro Delgado ${ }^{1} \&$ Efstathios Stefos ${ }^{2}$ \\ ${ }^{1}$ Universidad de las Fuerzas Armadas (ESPE), Sangolquí, Ecuador \\ ${ }^{2}$ National University of Education (UNAE), Azogues, Ecuador \\ Correspondence: Efstathios Stefos, National University of Education (UNAE), Azogues, Cañar, Parroquia Javier \\ Loyola (sector Chuquipata), Ecuador. Tel: 593-7-370-1200.E-mail: estefos@aegean.gr
}

Received: December 26, 2016

Accepted: January 6, 2017

Online Published: March 8, 2017

doi:10.5539/res.v9n2p35

URL: http://doi.org/10.5539/res.v9n2p35

\begin{abstract}
The purpose of this study is to investigate social characteristics of postgraduate students in Ecuador. The study was conducted with the use of a descriptive and multidimensional statistical analysis, and data from the National Survey of Employment, Unemployment and Underemployment corresponding to 2015. The descriptive analysis has shown the frequencies and percentages of the variables of the research. The multidimensional statistical analysis was used in order to show the main and most important criteria of differentiation and the classification in clusters of people being studied. The methods used are the factorial analysis of multiple correspondences that presents the criteria of differentiation and the hierarchical clustering that defines the groups of people due to their common characteristics.
\end{abstract}

Keywords: postgraduate students, Ecuador, multidimensional statistical analysis

\section{Introduction}

The aim of this study is to analyze and present the social characteristics of postgraduate students in Ecuador (Stefos, 2015). The levels of instruction provided by the institutions of the Higher Education system of Ecuador are as follows:

i. Technical or technological level of education is oriented to the development of skills and abilities, which allow the student to enhance the know-how. At this undergraduate level, correspond the professional titles of technician or higher education technologist awarded by higher technical, technological, pedagogical, conservatory institutes as well as art institutes.

ii. Third degree level focuses on the basic instruction of a discipline or the preparation to obtain a profession. This level corresponds to the bachelor degree and the professional degree or technical titles, and their equivalents. Only universities and polytechnic schools may grant third-level degrees.

iii. The fourth postgraduate level is oriented to the advanced professional training or the scientific and research specialization. This level corresponds to the professional title of specialisation and the academic master degree, $\mathrm{PhD}$ or its equivalent. To access the fourth level of instruction is required to have a third level professional degree granted by a university or polytechnic school (LOES, 2010).

The study investigates the social profile of the postgraduate students of the fourth educational level of the institutions of the Higher Education system in Ecuador. The results of the study may be used as a tool for the development of the postgraduate studies in Ecuador in accordance with the social profile of the postgraduate students in the country (Castellano et al., 2017; Stefos \& Efstathiou, 2013).

\section{Methodology}

The study used data from the National Survey on Employment, Unemployment and Underemployment of 2015 (INEC, 2015). In order to carry out this analysis, the database called ENEMDU-2015 provided by the INEC (National Institute of Statistics and Censuses) was used from the official webpage of INEC. After downloading the data, it was processed by the SPSS statistical software, the same one that allowed defining the most relevant variables and working with the information according to the statistical needs of the present study. Subsequently, 
the factor analysis was performed using the software SPAD in which five clusters were analyzed in agreement with their different characteristics.

In the context of the present study, a descriptive analysis and a multidimensional statistical analysis were carried out. The descriptive analysis shows the frequencies and percentages of the variables studied by the research (Athanasiadis, 1995). The multidimensional statistical analysis was used in order to show the main and most important criteria of differentiation and the classification in groups of people being investigated. The methods used are the factorial analysis of multiple correspondences which show the criteria of differentiation and the hierarchical clustering that defines the groups of people due to their common characteristics (Stefos et al., 2011). The factorial analysis of multiple correspondences was used in order to find how people differ according to their responses. This method investigates the correlation of the variables of the survey simultaneously. Factorial axes are the criteria of differentiation that express oppositions of people's responses. Hierarchical analysis shows the clusters of people according to their responses and common characteristics. This method also presents a classification chart that connects these clusters (Papapostolou et al., 2013).

\section{Descriptive Analysis}

$84.17 \%$ of population of postgraduate students live in urban areas, while $15.83 \%$ live in rural areas (Table 1).

Table 1. Area

\begin{tabular}{ccc}
\hline & $\mathrm{n}$ & $\%$ \\
\hline Urban & 17439 & $84.17 \%$ \\
Rural & 3280 & $15.83 \%$ \\
Total & 20719 & $100.00 \%$ \\
\hline
\end{tabular}

$43.67 \%$ of the respondents are men and $56.33 \%$ are women (Table 2).

Table 2. Sex

\begin{tabular}{ccc}
\hline & $\mathrm{n}$ & $\%$ \\
\hline Man & 9048 & $43.67 \%$ \\
Woman & 11670 & $56.33 \%$ \\
Total & 20719 & $100.00 \%$ \\
\hline
\end{tabular}

The age range that dominates in this population is between 21 and 30 years old with a percentage of $41.72 \%$, people between 31 and 40 represent $34.89 \%$, between 41 and 50 represent $17.70 \%$, and from 51 to 60 represent $5.69 \%$ of the population of the postgraduate students in Ecuador (Table 3).

Table 3. Age

\begin{tabular}{ccc}
\hline & $\mathrm{n}$ & $\%$ \\
\hline $21-30$ & 8644 & $41.72 \%$ \\
$31-40$ & 7229 & $34.89 \%$ \\
$41-50$ & 3668 & $17.70 \%$ \\
$51-60$ & 1178 & $5.69 \%$ \\
Total & 20719 & $100.00 \%$ \\
\hline
\end{tabular}

According to the collected data, $36.35 \%$ of the postgraduate students are married, $0.89 \%$ are separated, $7.36 \%$ are divorced, $0.99 \%$ are widowed, $9.88 \%$ are in free union, and $44.53 \%$ of postgraduate students are single men and women (Table 4). 
Table 4. Marital status

\begin{tabular}{ccc}
\hline & $\mathrm{n}$ & $\%$ \\
\hline Married & 7531 & $36.35 \%$ \\
Separated & 185 & $0.89 \%$ \\
Divorced & 1524 & $7.36 \%$ \\
Widowed & 205 & $0.99 \%$ \\
Free Union & 2048 & $9.88 \%$ \\
Single & 9226 & $44.53 \%$ \\
Total & 20719 & $100.00 \%$ \\
\hline
\end{tabular}

$98.24 \%$ of the postgraduate students attend classes, while $1.76 \%$ do not attend classes (Table 5).

Table 5. Attendance to classes

\begin{tabular}{ccc}
\hline & $\mathrm{n}$ & $\%$ \\
\hline Yes & 20353 & $98.24 \%$ \\
No & 365 & $1.76 \%$ \\
Total & 20719 & $100.00 \%$ \\
\hline
\end{tabular}

We can see that the main language is Spanish representing $84.17 \%, 14.61 \%$ of people speak Spanish and a foreign language, and $1.22 \%$ speak an indigenous language and Spanish (Table 6).

Table 6. Spoken language

\begin{tabular}{ccc}
\hline & $\mathrm{n}$ & $\%$ \\
\hline Spanish only & 17439 & $84.17 \%$ \\
Spanish and foreign language & 3028 & $14.61 \%$ \\
Indigenous language and Spanish & 252 & $1.22 \%$ \\
Total & 20719 & $100.00 \%$ \\
\hline
\end{tabular}

We can observe that $92.71 \%$ are considered mestizo, $1.97 \%$ mulatto, $1.71 \%$ black, $1.51 \%$ white, $1.22 \%$ indigenous, $0.48 \%$ montubio, and $0.26 \%$ Afro-Ecuadorian (Table 7).

Table 7. Ethnic self-identification

\begin{tabular}{ccc}
\hline & $\mathrm{n}$ & $\%$ \\
\hline Mestizo & 19209 & $92.71 \%$ \\
Mulatto & 407 & $1.97 \%$ \\
Black & 355 & $1.71 \%$ \\
White & 313 & $1.51 \%$ \\
Indigenous & 252 & $1.22 \%$ \\
Montubio & 99 & $0.48 \%$ \\
Afro-Ecuadorian & 53 & $0.26 \%$ \\
Other & 30 & $0.15 \%$ \\
Total & 20719 & $100.00 \%$ \\
\hline
\end{tabular}


$93.76 \%$ of population has an activated cellphone, and $78.52 \%$ have a smartphone (Tables 8 and 9 ).

Table 8. Students who have an activated cell phone

\begin{tabular}{ccc}
\hline & $\mathrm{n}$ & $\%$ \\
\hline Yes & 19425 & $93.76 \%$ \\
No & 198 & $0.95 \%$ \\
NA & 1095 & $5.29 \%$ \\
Total & 20719 & $100.00 \%$ \\
\hline
\end{tabular}

Table 9. Students who have an activated smartphone

\begin{tabular}{ccc}
\hline & $\mathrm{n}$ & $\%$ \\
\hline Yes & 16267 & $78.52 \%$ \\
No & 3158 & $15.24 \%$ \\
NA & 1293 & $6.24 \%$ \\
Total & 20719 & $100.00 \%$ \\
\hline
\end{tabular}

$94.46 \%$ of postgraduate students used a computer in the last 12 months, while $0.26 \%$ did not used it (Table 10$)$.

Table 10. Use of a computer in the last 12 months

\begin{tabular}{ccc}
\hline & $\mathrm{n}$ & $\%$ \\
\hline Yes & 19570 & $94.46 \%$ \\
No & 53 & $0.26 \%$ \\
NA & 1095 & $5.29 \%$ \\
Total & 20719 & $100.00 \%$ \\
\hline
\end{tabular}

$94.49 \%$ of students used internet during the last 12 months, while $0.22 \%$ did not (Table 11 ).

Table 11. Use of internet in the last 12 months

\begin{tabular}{ccc}
\hline & $\mathrm{n}$ & $\%$ \\
\hline Yes & 19578 & $94.49 \%$ \\
No & 45 & $0.22 \%$ \\
NA & 1096 & $5.29 \%$ \\
Total & 20719 & $100.00 \%$ \\
\hline
\end{tabular}

We can see that $64.07 \%$ of postgraduate students used internet more frequently at home, $28.27 \%$ at work, $1.23 \%$ used internet in public access centers, $0.56 \%$ at another person's home, and $0.33 \%$ in an educational institution (Table 12). 
Table 12. Frequent use of internet in the last 12 months

\begin{tabular}{ccc}
\hline & $\mathrm{n}$ & $\%$ \\
\hline Home & 13274 & $64.07 \%$ \\
Work & 5858 & $28.27 \%$ \\
Public access center & 255 & $1.23 \%$ \\
Someone else's house & 115 & $0.56 \%$ \\
Educational institution & 68 & $0.33 \%$ \\
NA & 1148 & $5.54 \%$ \\
Total & 20719 & $100.00 \%$ \\
\hline
\end{tabular}

$42.32 \%$ of postgraduate students have used the internet to obtain information, $20.53 \%$ for general communication, $16.60 \%$ for education and learning, $11.68 \%$ for work reasons, and $3.32 \%$ for transactions with agencies (Table 13).

Table 13. Reasons for using the internet in the last 12 months

\begin{tabular}{ccc}
\hline & $\mathrm{n}$ & $\%$ \\
\hline To get information & 8769 & $42.32 \%$ \\
Communication in general & 4254 & $20.53 \%$ \\
Education and learning & 3439 & $16.60 \%$ \\
Reasons for work & 2420 & $11.68 \%$ \\
Transactions with agencies & 689 & $3.32 \%$ \\
NA & 1148 & $5.54 \%$ \\
Total & 20719 & $100.00 \%$ \\
\hline
\end{tabular}

$88.01 \%$ of postgraduate students have used internet at least once a day in the last 12 months, and $6.45 \%$ at least once a week (Table 14).

Table 14. Frequency of the usage of internet in the last 12 months

\begin{tabular}{ccc}
\hline & $\mathrm{n}$ & $\%$ \\
\hline At least once a day & 18234 & $88.01 \%$ \\
At least once a week & 1336 & $6.45 \%$ \\
NA & 1148 & $5.54 \%$ \\
Total & 20719 & $100.00 \%$ \\
\hline
\end{tabular}

$68.20 \%$ of postgraduate students live in the highlands region, $27.87 \%$ in the coast region, $3.20 \%$ in the Amazon region, and $0.73 \%$ live in island region (Table 15 ).

Table 15. Natural region

\begin{tabular}{ccc}
\hline & $\mathrm{n}$ & $\%$ \\
\hline Highlands & 14130 & $68.20 \%$ \\
Coast & 5774 & $27.87 \%$ \\
Amazon & 663 & $3.20 \%$ \\
Island & 151 & $0.73 \%$ \\
Total & 20719 & $100.00 \%$ \\
\hline
\end{tabular}


The highest percentage in the branch of activity of the students corresponds to teaching with $28.85 \%$; public administration, defense and social security with $16.94 \%$; social activities and health services $10.47 \%$; construction 6.65\%; professional, scientific and technical activities 5.73\%; trade, repair vehicles $4.09 \%$; information and communication 3.18\%; manufacturing industries 3.17\%; financial and insurance activities $2.58 \%$; transport and storage $1.08 \%$; electricity, gas, air conditioning supplies $0.81 \%$; accommodation and food services $0.56 \%$; other service activities $0.54 \%$; activities and administrative and support services $0.32 \%$; arts, entertainment and recreation $0.19 \%$ (Table 16).

Table 16. Branch of activity

\begin{tabular}{lcc}
\hline & $\mathrm{n}$ & $\%$ \\
\hline Teaching & 5977 & $28.85 \%$ \\
Public administration, defense and social security & 3509 & $16.94 \%$ \\
Social activities and health services & 2169 & $10.47 \%$ \\
Construction & 1377 & $6.65 \%$ \\
Professional, scientific and technical activities & 1187 & $5.73 \%$ \\
Trade and repair of vehicles & 847 & $4.09 \%$ \\
Information and communication & 658 & $3.18 \%$ \\
Manufacturing Industries & 657 & $3.17 \%$ \\
Financial and insurance activities & 535 & $2.58 \%$ \\
Transport and storage & 224 & $1.08 \%$ \\
Electricity, gas, air conditioning supplies & 168 & $0.81 \%$ \\
Accommodation activities and food services & 115 & $0.56 \%$ \\
Other service activities & 112 & $0.54 \%$ \\
Administrative and support activities and services & 65 & $0.32 \%$ \\
Arts, entertainment and recreation & 40 & $0.19 \%$ \\
NA & 3078 & $14.85 \%$ \\
Total & 20719 & $100.00 \%$ \\
\hline
\end{tabular}

Regarding income poverty, $97.82 \%$ belong to those who are considered as non-poor, while $1.99 \%$ belong to those who are considered poor (Table 17).

Table 17. Income poverty

\begin{tabular}{ccc}
\hline & $\mathrm{n}$ & $\%$ \\
\hline Not poor & 20266 & $97.82 \%$ \\
Poor & 411 & $1.99 \%$ \\
NA & 41 & $0.20 \%$ \\
Total & 20719 & $100.00 \%$ \\
\hline
\end{tabular}

$99.06 \%$ of the postgraduate students are considered as non-indigent, while $0.74 \%$ are considered as indigent (Table 18). 
Table 18. Extreme income poverty

\begin{tabular}{ccc}
\hline & $\mathrm{n}$ & $\%$ \\
\hline Not indigent & 20523 & $99.06 \%$ \\
Indigent & 154 & $0.74 \%$ \\
$\mathrm{NA}$ & 41 & $0.20 \%$ \\
Total & 20719 & $100.00 \%$ \\
\hline
\end{tabular}

The condition of activity with the highest percentage is related to the suitable employment with $74.61 \%$, economically inactive population with $11.98 \%$, another inadequate employment with $4.95 \%$, open unemployment with $2.88 \%$, non-classified employment $2.85 \%$, underemployment due to insufficient working time with $1.94 \%$, and unpaid employment $0.79 \%$ (Table 19 ).

Table 19. Activity condition

\begin{tabular}{lcc}
\hline & $\mathrm{n}$ & $\%$ \\
\hline Suitable employment & 15458 & $74.61 \%$ \\
Economically inactive population & 2481 & $11.98 \%$ \\
Other inadequate employment & 1026 & $4.95 \%$ \\
Open unemployment & 597 & $2.88 \%$ \\
Not classified jobs & 590 & $2.85 \%$ \\
Underemployment due to insufficient working time & 402 & $1.94 \%$ \\
Unpaid employment & 164 & $0.79 \%$ \\
Total & 20719 & $100.00 \%$ \\
\hline
\end{tabular}

\section{The Factorial Analysis of Multiple Correspondences}

The factorial analysis of multiple correspondence method was used to find out how people who participated in the survey are differentiated according to their responses (Stefos \& Koulianidi, 2016). The criteria that differentiate the postgraduate students are:

\section{First criterion of differentiation (percentage of inertia 16.32\%)}

In the first criterion there are postgraduate students who have used computers and internet during the last 12 months, have a cell phone or smartphone and declared that they are not poor. On the other hand, there are students with access to computer and internet who declared that they are poor and work doing art, entertainment, recreation, trade and repair of vehicles.

\section{Second criterion of differentiation (percentage of inertia 6.52\%)}

In the second criterion of differentiation there are students who declared that they have adequate employment, they are teachers between 51 and 60 years of age, who aren't poor nor married. On the other hand, there are postgraduate students between 21 and 30 years old who are single, poor, mestizos and live in the highland region.

Third criterion of differentiation (percentage of inertia $6.08 \%$ )

In the third criterion of differentiation, on one hand, there are students who consider themselves indigenous, speak indigenous language and Spanish, use internet at least once a week and live in rural areas. On the other hand, there are students who have declared that they are mestizos, work in public administration, defense and social security, have smartphones and live in urban areas. 


\section{Hierarchical Analysis}

The hierarchical analysis led to five clusters that are shown in the following figure (Benzécri, 1992).

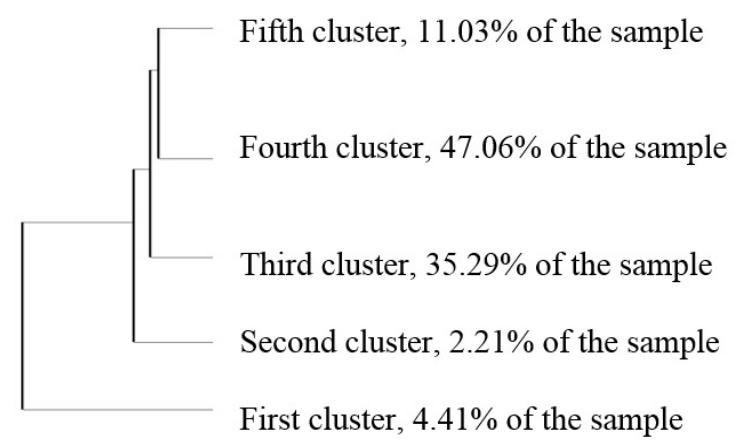

Figure 1. The classification chart

\section{First cluster ( $4.41 \%$ of the sample)}

The postgraduate students of the first cluster have an activated cell phone or smartphone, used computers and internet during the last 12 months at their homes and used the internet at least once a day.

Second cluster (2.21\% of the sample)

Students of the second cluster stated that they are indigenous and mestizo who speak indigenous and Spanish language, most of them work in accommodation and food services or are unemployed.

Third cluster (35.29\% of the sample)

Students of the third cluster stated that have suitable employment, most of them are teachers between 41 and 60 years of age, used the internet during the past 12 months in their home and most of them are married or separated.

\section{Fourth cluster ( $47.06 \%$ of the sample)}

Students of the fourth cluster responded that they have used the internet during the last 12 months in their work or home at least once a day, most of them are single and work in public administration, defense, social security and manufacturing industries.

\section{Fifth cluster (11.03\% of the sample)}

The fifth cluster consists of postgraduate students who stated that they are economically inactive, they are between 21 and 30 years old and are single.

The differences of the groups are shown in Figure 2 where the graph of correspondence analysis (factorial level $1 \times 2)$ presents the centroids of the five clusters on the two axes. In addition, it defines the differences and similarities between the people of the five clusters (Stefos \& Papapostolou, 2013; Olivier, 2008). 


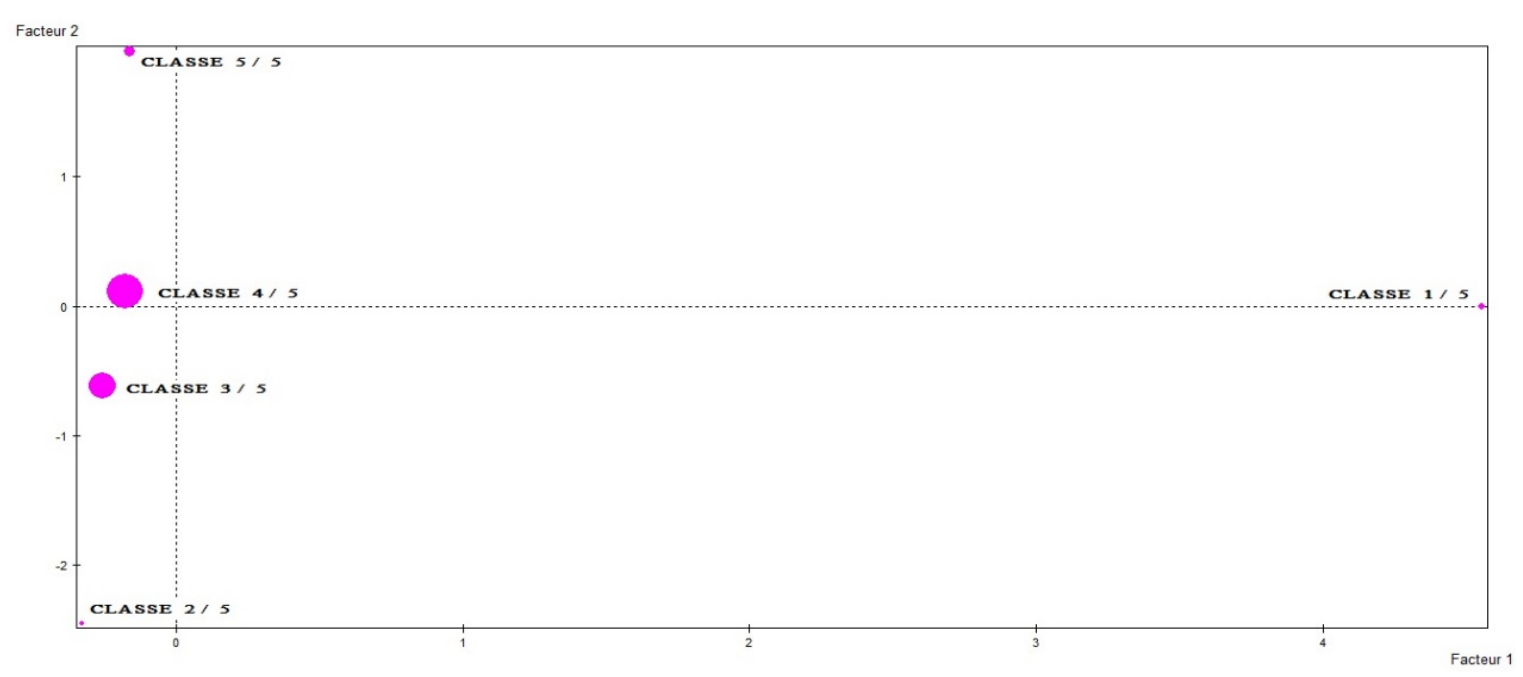

Figure 2. Correspondence analysis

\section{Conclusion}

The aim of the present study was to investigate the social characteristics of postgraduate students in Ecuador. In the framework of this study, a multidimensional statistical analysis was performed, which confirmed the results of the descriptive analysis (Koulianidi \& Stefos, 2015).

The majority of postgraduate students in Ecuador live in urban areas (84.17\%); 56.33\% are women; $44.53 \%$ are single and $36.35 \%$ are married; $98.24 \%$ attend classes; $84.17 \%$ speak only Spanish; $92.71 \%$ are considered mestizos; only $1.22 \%$ are indigenous; $93.76 \%$ have a cell phone and $78.52 \%$ have a smartphone; $94.46 \%$ used computers during the last 12 months and $94.49 \%$ used the internet; $64.07 \%$ used internet in their home and $28.27 \%$ in their work; only $16.60 \%$ of postgraduate students stated that they used the internet for education and learning; $88.01 \%$ used the internet at least once a day; $68.20 \%$ of postgraduate students live in the highland region of Ecuador; $28.85 \%$ are teachers and $16.94 \%$ work in public administration, defense and social security; only $1.99 \%$ stated that they are poor and $74.61 \%$ responded that they have suitable employment (Valdivieso et al., 2017; Kampouropoulou et al., 2015).

\section{Acknowledgments}

We would like to express our deepest gratitude to the Faculty of Humanities of the University of the Aegean for donating the statistical software SPAD v.4.5 used in this study.

\section{References}

Athanasiadis, I. (1995). Correspondence Analysis and Hierarchical Classification (pp. 51-56). Athens: New Technologies Editions.

Benzécri, P. (1992). Correspondence Analysis Handbook. New York: Dekker.

Castellano, J. M., Stefos, E., \& Williams, G. L. G. (2017). The Educational and Social Profile of the Indigenous People of Ecuador: A Multidimensional Analysis. Review of European Studies, 9(1), 137-147. https://doi.org/10.5539/res.v9n1p137

Instituto Nacional de Estadística y Censos-INEC. (2015). Encuesta Nacional de Empleo, Desempleo y Subempleo-ENEMDU, 2015. Quito, Retrieved from http://www.ecuadorencifras.gob.ec/enemdu-2015/

Kampouropoulou, M., Fokiali, P., Efstathiou, I., Koutris, T., \& Stefos, E. (2015). Students' Views on the Use of a Virtual Educational Museum. Review of European Studies, 7(11), 1-6. https://doi.org/10.5539/res.v7n11p1

Koulianidi, G., \& Stefos, E. (2015). Consequences of Dietary Habits and Endocrine Disruptors in School Performance of Children Aged 10-12 in Greece. American Journal of Food Science and Nutrition, 2(6), 113-120. 
Olivier, M. (2008). The analysis of quantitative data (pp. 86-88). Athens: Topos.

Papapostolou, I., \& Stefos, E. (2013). Qualitative analysis on pedagogical research. Methodological approaches. In I. Papapostolou (Ed.), Educational activities. Teaching Interventions in Secondary Education (pp. 244-251). Rhodes: Evdimos Editions.

Papapostolou, I., Papapostoulou, K., \& Stefos, E. (2013). Educational Research. From Qualitative to Quantitative analysis (p. 178). Rhodes: Evdimos Editions.

Presidencia de la Republica del Ecuador. (2010). Ley Organica de Educacion Superior (LOES). Quito, Ecuador.

Sarmiento, N. M., Paredes, P. A. M., \& Stefos, E. (2016). Deaths by Suicide in Ecuador: A Quantitative Data Analysis. Review of European Studies, 8(1), 145-156. https://doi.org/10.5539/res.v8n1p145

Stefos, E. (2015). Causes of Death of Indigenous Ecuadorians. International Journal of Clinical Medicine Research, 2(6), 65-70.

Stefos, E., \& Efstathiou, I. (2013). Quantitative analysis of the data of the School of Trianta during the period of 1906-1916. In I. Papapostolou (Ed.), Educational activities. Teaching Interventions in Secondary Education (pp. 29-57). Rhodes: Evdimos Editions.

Stefos, E., \& Koulianidi, G. (2016). Nutrition Data Analysis Using R: Applications in Higher Education. Health Sciences Research, 3(1), 10-16.

Stefos, E., \& Papapostolou, I. (2013). Research Methodology. Processes and suggestions (p. 406). Rhodes: Evdimos Editions.

Stefos, E., Athanasiadis I., Gialamas, B., \& Tsolakidis, C. (2011). The Use of New Technologies and the Project Method in Teaching Statistics: A Case Study in Higher Education. HMS i JME, 3, 84-100.

Valdivieso, G., Stefos, E., \& Lalama R. (2017). The Ecuadorian Amazon: A Data Analysis of Social and Educational Characteristics of the Population. Review of European Studies, 9(1), 120-129. https://doi.org/10.5539/res.v9n1p120

\section{Copyrights}

Copyright for this article is retained by the author(s), with first publication rights granted to the journal.

This is an open-access article distributed under the terms and conditions of the Creative Commons Attribution license (http://creativecommons.org/licenses/by/4.0/). 